\title{
The Relationship between Airlines' Corporate Image and the Expectation toward Inflight Hospitality Services
}

\author{
Ahmad Azmi M.Ariffin \\ Ehsaneh N.M. Nameghi \\ Amin Khakizadeh \\ Graduate School of Business, Universiti Kebangsaan Malaysia \\ 43600 UKM Bangi, Malaysia \\ Email: aama@ukm.my
}

\section{Doi:10.5901/ajis.2013.v2n11p179}

\begin{abstract}
This present study attempts to provide empirical evidence on the influence of the airline's corporate image on the passengers' expectations of airline hospitality. Specifically, this study seeks to explain the impacts of the two specific dimensions of corporate image namely financial corporate image, as well as managerial corporate image on passengers' airline hospitality expectations. This study involving questionnaire surveys of 546 air travellers was conducted at Kuala Lumpur International Airport (KLIA). Partial Least Squares (PLS) was used as the primary statistical analysis method to test the hypotheses of this study. The findings of this study revealed that out of the two dimensions of corporate image, only the managerial corporate image has a strong positive relationship with passengers' expectation towards airline hospitality.
\end{abstract}

\section{Introduction}

Corporate image refers to corporation perception revealed in the associations kept in customer mind (Park et al., 2004). Corporate image has been considered strategically important because of its role in an achievement of the long-term objectives of the organizations and its strong linkage with companies' mission and vision statement (Abratt \& Mofokeng, 2000). Park et al. (2004) have emphasized on an importance of corporate image as a factor that evaluates service and company performance. Zins (2001) pointed that corporate image has a significant role in airlines' identity, and its communicational role in the strategic management instrument is undeniable. The airline image has impact particularly on expectation of passengers who have authority and feel free in airline selection.

The present study looks at the impact of corporate image on passengers' expectations from airline hospitality. Understanding airline company image impact will help airline managers make decisions about highlighting or diminishing the role of corporate image on their airline quality expectations and image.

\section{Corporate Image}

Bloemer et al. (1998) explained the relationship between corporate image and customer behavior which was mediated by satisfaction and perceived quality in banking system. It is believed that when services assessment are complicated, corporate image can be a significant issue having an impact on quality perception, consumers assessment from service satisfaction, as well as consumer loyalty. Cameran et al. (2010) and Hu et al. (2009) have also counted satisfaction as the most significant consequence of firms' effectiveness. In addition a positive corporate image can be considered as competitive advantage for organization which differentiates company from its competitors (Bravo et al., 2010).

Corporate image influences consumers' company selection when service characteristics are very complex to assess. Corporate image is understood to generate a halo effect on consumers' satisfaction conclusion. Corporate image is found and expanded in customers mind throughout experience and communication (Andreassen \& Lindestad, 1998). On the other hand hospitality, in essence, is also based on experience and communication. Hospitality without feeling, experiencing and connection with others, cannot be understood and exists. Hence this can be considered as a good indicator which shows the relationship between corporate image and hospitality. 
Corporate image has also been investigated in airline industry (Zins 2001). Zins (2001) found that image of airline influences consumer loyalty mediated by perceived service quality and satisfaction. This study finds strong association among image and future loyalty. Although service quality and perceived corporate image are powerfully interdependent, a strong corporate image is not able to mask the poor service and hospitality level in long run. Pina et al. (2006) has emphasized on the impact of high quality service provision on creating corporate image. Pina et al. (2006) have found the level of perceived fit among the company brand and the service extension have impact on the perceived quality of the extension. This consequently will have impact on corporate image, particularly for those company brands which initially contained extremely high rank images.

\subsection{Financial Reputation \& Managerial Reputation}

Corporate reputation of the company is defined by two important characteristics, which are financial and managerial reputation of the company. Financial reputation of the company refers to the trend of the company to do better than opponents, identify, use market opportunities and its prospect for future growth.

Financial reputation of the company can be explained from stakeholder perspective or the customers' perspective. Financial reputation from consumers' perspectives refers to items such as: seems it would be a good venture, come into view to make financially proper choices, has a powerful record of profitability, financially it performs well, look like to have a obvious image of its upcoming and come into view to be conscious of its task to the public (Walsh \& Beatty, 2007).

For the purpose of present study, financial reputation has been investigated from consumer perspective. This means consumers perceive airline (national carriers) companies in terms of their financial standing, stability and other related financial aspects. Like financial reputation, managerial reputation also can be considered from two perspectives: managerial or organization perspective and customer perspective.

Walsh and Beatty (2007) have defined managerial corporate reputation based on customer orientation. This refers to consumers' assessment of company's reputation based on customer orientation elements such as company's employees who treat customers courteously, their level of company's concern about customers and whether they treat their customers fairly or not. To conclude, present study follows analogous school of thought which considers corporate reputation and image similar and will look at corporate image (Gotsi \& Wilson, 2001) from customer perspective. The impact of company image can be anticipated to turn out to be more significant for higher and complex service levels (Cretu \& Brodie, 2007). Since an airline industry can be considered as a high-level service, present study considers an important role for corporate image impact on passengers' expectations from national carriers.

Past studies have clearly showed that corporate image has strong impacts on customers' expectation in the context of product as well as service (Kijewski, 1993; Shapiro, 1983). The reputation of company helps buyers to enhance their knowledge about companies' product or at least to create awareness on the existence of the company. Corporate image or reputation can be improved by providing high quality offering and effectively leading and organizing the information flow outside the company (Kijewski et al., 1993).

In general, corporate image or corporate reputation represents the company's status in the eye of the public. Based on the theory of perceived service quality (Grönroos, 1984), positive relationship between corporate image and customer expectation toward hospitality is expected. The more favorable the corporate image with regards to their financial reputation or managerial reputation, the higher the expectation on their level of hospitality hosting behavior. Therefore, it is anticipated in this study that:

H1: Financial corporate image is positively related to passengers' expectation of the airline hospitality.

H2: Managerial corporate image is positively related to passengers' expectation of the airline hospitality.

\section{Methodology}

\subsection{Data Collection}

To collect the data, structured questionnaires were distributed among air travellers at Kuala Lumpur International Airport (KLIA), and 546 questionnaires were completed. All the scales employed in this study were adopted from established measurements. Partial least squares (PLS) was the main statistical method used to test the hypotheses.

Table 1 summarized the respondent's profile of this study. The profiles show a relatively balanced sample of males and females in which $52.9 \%$ of the respondents were male. Most of the respondents (39.2\%) fall in the age range of 20 to 30 years old and only $2.8 \%$ fall in the 60 and above range. With respect to academic qualifications, $19 \%$ of the 
respondents had obtained their postgraduate degrees, and a majority (45.6\%) of the respondents had received a bachelor's degree. Most of the respondents fall into the two income categories: below RM 2000 (26.2\%) and RM 2000RM 4000 (30.8\%).

Table 1: Profile of Respondents

\begin{tabular}{|c|c|c|c|}
\hline \multicolumn{2}{|c|}{$\begin{array}{l}\text { Demographic } \\
\text { Characteristics }\end{array}$} & \multirow[t]{2}{*}{$\mathrm{N}$} & \multirow[t]{2}{*}{ Percent (\%) } \\
\hline Gender & & & \\
\hline i. & Male & 289 & 52.9 \\
\hline ii. & Female & 257 & 47.1 \\
\hline \multicolumn{4}{|l|}{ Age } \\
\hline i. & Below 20 & 42 & 7.7 \\
\hline ii. & 20 to $<30$ & 214 & 39.2 \\
\hline iii. & 30 to $<40$ & 150 & 27.5 \\
\hline iv. & 40 to $<50$ & 86 & 15.8 \\
\hline v. & 50 to $<60$ & 38 & 7.0 \\
\hline vi. & $60 \&$ Over & 16 & 2.8 \\
\hline \multicolumn{4}{|c|}{ Highest Level of Education } \\
\hline i. & Postgraduate Degree & 104 & 19.0 \\
\hline ii. & Bachelor Degree & 249 & 45.6 \\
\hline iii. & Diploma & 116 & 21.2 \\
\hline iv. & Secondary School & 57 & 10.4 \\
\hline v. & Below Secondary & 1 & 0.3 \\
\hline vi. & Other & 19 & 3.5 \\
\hline \multicolumn{4}{|c|}{ Occupation } \\
\hline i. & Student & 96 & 17.6 \\
\hline ii. & Employed & 306 & 56.0 \\
\hline iii. & Self-Employed & 84 & 15.4 \\
\hline iv. & Unemployed/Retired & 21 & 3.8 \\
\hline v. & Others & 39 & 7.2 \\
\hline \multicolumn{4}{|c|}{ Monthly Income } \\
\hline i. & Below RM 2000 & 143 & 26.2 \\
\hline ii. & RM2000 < RM5000 & 168 & 30.8 \\
\hline iii. & $\mathrm{RM} 5000<\mathrm{RM} 8000$ & 99 & 18.1 \\
\hline iv. & RM8000 < RM11000 & 46 & 8.4 \\
\hline v. & $\mathrm{RM} 11000<\mathrm{RM} 14000$ & 42 & 7.7 \\
\hline vi. & RM 14000 \& above & 48 & 8.8 \\
\hline \multicolumn{4}{|l|}{ Ethnicity } \\
\hline i. & Malay & 284 & 52.0 \\
\hline ii. & Chinese & 78 & 14.3 \\
\hline iii. & Indian & 34 & 6.2 \\
\hline iv. & Others(Malaysians) & 23 & 4.2 \\
\hline v. & Non-Malaysians & 127 & 23.3 \\
\hline
\end{tabular}

The reliability test for the variables in this study is presented in Table. 2 . The reliability test for all the variables recorded strong internal consistency with coefficient alphas above 0.9 , which exceed the 0.7 cut-off point recommended for theory testing by Nunnally (1987). Table 2 also presents the means and standard deviations for the variables in this study. All the variables were measured on a six-point Likert scale. The mean scores for all variables range from 3.87 to 4.56 .

Table 2: Reliability Test

\begin{tabular}{lcccc}
\hline \multicolumn{1}{c}{ Variables } & Mean & Standard Deviation & No. of Items & Cronbach's Alpha \\
\hline Airline Hospitality & 4.56 & .885 & 19 & 0.96 \\
Financial Corporate Image & 3.87 & 1.053 & 5 & 0.91 \\
Managerial Corporate Image & 4.05 & .9827 & 7 & 0.92 \\
\hline
\end{tabular}




\subsection{Construct Validity}

According to Sekaran and Bougie (2010), the construct validity refers to the degree to which the model employed in the study fits the theories being tested. Convergent validity and discriminant validity help to ensure the model's ability to measure the construct (O'Leary-Kelly and Vokurka, 1998). To ensure the construct validity, the loading and cross-loading of the items were investigated. Based on Hair et al. (2010), the value of significant loading is 0.5 and above. The results of this study show that all the items representing one construct are loaded highly on that construct while the other constructs are loaded much lower. Therefore, the construct validity was confirmed in the present study.

\subsection{Convergent Validity}

Convergent validity refers to the extent to which the methods used to measure the same variable produced similar results (O'Leary-Kelly and Vokurka, 1998). Composite reliability, average variance extracted as well as factor loading can be used to measure convergent validity (Hair et al., 2010). The composite reliability, as shown in Table 3, exceeds the suggested cut off point of 0.7 (Hair et al., 2010). The average variance extracted (AVE) exceeds the recommended value of 0.5 (Barclay et al., 1995). The (AVE) in the study were in the range of 0.57 and 0.74 .

Table 3: Measurement Model

\begin{tabular}{lccc}
\hline \multicolumn{1}{c}{ Constructs } & AVE & Composite Reliability & Cronbachs Alpha \\
\hline Airline Hospitality & 0.5703 & 0.961 & 0.961 \\
Financial C.Image & 0.7378 & 0.9336 & 0.9121 \\
Managerial C.Image & 0.6802 & 0.937 & 0.9215 \\
\hline
\end{tabular}

\subsection{Discriminant Validity}

To ensure discriminant validity (which is the degree to which items can measure different constructs) correlational analysis among the construct measurements was employed. Compeau et al. (1999) states that the items should be loaded higher in the construct in which they belong. Table 4 represents the correlations among the constructs. Constructs correlation are less that (AVE) of each construct; therefore, discriminant validity exists among the constructs in the present study.

Table 4: Discriminant Validity

\begin{tabular}{lccc}
\hline \multicolumn{1}{c}{ Constructs } & 1 & 2 & 3 \\
\hline 1. Airline Hospitality & $\mathbf{0 . 5 7 0 3}$ & & \\
2. Financial C.Image & 0.3422 & $\mathbf{0 . 7 3 7 8}$ & \\
3. Managerial C.Image & 0.4877 & 0.728 & $\mathbf{0 . 6 8 0 2}$ \\
\hline
\end{tabular}

\section{Findings}

The results of the hypotheses tests are presented in Table 5. The $\mathrm{R}^{2}$ value for passengers' airline hospitality expectations is 0.240 , which suggests that $24 \%$ of the variance in airline hospitality expectation can be explained by corporate image dimensions. Managerial corporate image is positively related $(b=0.548, p<0.01)$ to the level of customer's airline hospitality expectations. The relationship between financial corporate image and passengers expectation from airline hospitality was found be not significant. Thus, $\mathrm{H} 2$ was supported while $\mathrm{H} 1$ was not supported.

Table 5: Hypotheses Testing and Path Coefficients

\begin{tabular}{ccccc}
\hline Hypothesis & Relationship & Coefficient & t-value & Supported \\
\hline H1 & FCORP----> AIRHOS & -0.0789 & 1.3466 & Not Supported \\
H2 & MCORP ----> AIRHOS & 0.5483 & 9.5014 & Supported \\
\hline
\end{tabular}

\section{Discussion}




\subsection{The relationship between financial corporate image and passengers' expectation on airline hospitality (H1)}

The findings of this present study do not support hypothesis H1. More specifically, the findings indicate that financial corporate image has no significant bearing on passenger expectations of airline hospitality. The plausible explanation for this may be that passengers are not really bothered about very detailed and specific type of information regarding an airline company, such as its financial standing. According to the findings of Hoenen et al. (2005), passengers assess the quality of the treatment and the provision of services by an airline based on the halo perspective rather than the summary perspective. In other words, the halo effects explain attitudes better than the summary effects when it comes to evaluating the service quality of airlines (Hoenen et al., 2005). Hence, it can be concluded that passengers gauge quality more from an overall perspective rather than from an elaborate and detailed approach. This means that passengers will not focus on detailed issues concerning airlines, such as the financial standing of the airlines, and they will not consider it as an indicator of their expectations of the hospitality provided during their flights.

Furthermore, Gilbert and Wong (2003) stated that passengers with different travel purposes would have different expectations of the in-flight hospitality offered. According to this finding passengers with business purposes have lower expectations of the hospitality provided compared to passengers flying for leisure purposes. Therefore, it can be concluded that leisure purpose travellers are more concerned about airline hospitality and the quality of the services, and they do not consider other issues, such the financial status of the airlines company, as an important indicator to shape their expectations. In other words, the expectations of leisure purpose travellers with regard to airline hospitality are not influenced by the financial image of the airlines. Of course, this finding might not apply to business purpose travellers and they may have more information about the airlines companies and may consider the financial standing of the company as an important element to determine their expectations toward airlines hospitality.

\subsection{The relationship between managerial corporate image and passengers' expectation on airline hospitality $(\mathrm{H} 2)$}

It was discovered in this study that managerial corporate image is positively related to passenger expectations of hospitality. This suggests that the higher the managerial image of the company, the greater will be the expectation of the passengers with regard to airline hospitality. An "interactive marketing" approach which is about the manner in which the host treats the guests in order to satisfy their requirements (Brodie et al., 2009) will be employed to explain hypothesis $\mathrm{H} 2$.

If passengers have a positive image of the airline's cabin crew, this will boost their expectations of that particular airline. Positive image here refers to the passengers' understanding of the level of job satisfaction of the cabin crew as well as their assessment of the manner in which the cabin crew treats them. If the cabin crew is contented with their job and treat the passengers well, then the passengers in turn will be pleased with the service and hospitality rendered, thus leading to a memorable and joyful experience for them (Cheng et al., 2008; Yeh, 2009).

Hence, it can be concluded that the satisfaction of the crew (which can easily be detected by the crew's reaction and the way they treat their passengers) is an important indicator of an airline company's image, which influences the expectations and satisfaction of passengers. This conclusion is consistent with the findings of previous studies. It was stated by Kandampully and $\mathrm{Hu}$ (2007) that a good corporate image leads to expectations of quality and consumer satisfaction, which in turn influences consumer loyalty.

In this study, items such as "the company seems to have employees who are concerned about customer needs", which is a functional feature of services, were used to measure managerial corporate image. The functional features of services (how services are presented, such as the behaviour of the cabin crew, the way they treat passengers, and the hospitality that is extended) have a greater effect on the emotional feelings of consumers rather than the technical features (what is presented) (Kandampully \& $\mathrm{Hu}, 2007$ ). The functional features of the service add value and provide passengers with a memorable experience. It can thus be concluded that the impact that an airline's cabin crew treatment manner has on the feelings and expectations of passengers is understandable (Chen, 2008). In fact, the attentiveness of the cabin crew as well as their considerate behaviour improves the passenger's perception and consequently leads to the formation of a positive airline image.

In the present study, the managerial corporate image was evaluated according to whether "the company looks like a good company to work for" as well as "the level of strength and reliability of the company". A good company is able to provide a pleasant environment for both its staff as well as its customers at the same time. For example, the slogan of the Ritz Carlton Hotel, "We are ladies and gentlemen serving ladies and gentlemen", conveys a powerful "image" of service to both its guests and its staff simultaneously. This means that the Ritz Carlton is portraying itself as a hotel that is a good 
place to work in. To the Ritz Carlton, both customer groups (guests as external customers and employees as internal customers) are not only considered to be the keys to the success of the firm, but may also help it to attain an outstanding service image in the market. Evidently, the main characteristic of the Ritz Carlton is its excellent leadership in giving value to both its employees as well as its customers (Kandampully \& Hu, 2007).

Excellent leadership is another representation of managerial corporate image which some airline companies try to portray in their slogans. For example, the standard slogan of Southwest Airlines is "customers come second - and still get great service". The main belief of Southwest is that "the better its people are treated the better they perform". This main belief, as well as the appropriate leadership, helped Southwest achieve three very significant outcomes, namely: employee relationships, service culture and client relationship. A good leadership attracts commitment and loyalty from its employees, and this is what distinguishes Southwest from its competitors. In conclusion, the success of an airline company depends greatly on a good organization of human resources leading to higher expectations as well as commitment of employees to services, which thereby improves the service received by customers (Worsfold, 1999).

Other studies have also shown that there is a connection between satisfied clients and satisfied staff (Yang \& Coates, 2010) and the latter will be constantly committed to their companies (Yang, 2010). When a company is mindful of the needs of its staff, those who are on the receiving end of the services experience greater satisfaction (Yang \& Coates, 2010), enjoy quality relationships (Kim \& Cha, 2002), add to their purchases (Kim \& Cha, 2002) and make more recommendations by word-of mouth (Pizam \& Ellis, 1999).

Furthermore, a company's sensitivity when it comes to environmental issues is another managerial corporate image item which significantly shapes the perception of consumers towards that particular company. In the aviation industry, it appears that the environmental concerns of passengers as well as airlines have grown in recent years. Mayer et al. (2012) stated that $50 \%$ of passengers are able to differentiate between airlines by their environmental friendly behaviour (such as by using organic foods and bio fuels, and having a positive attitude towards the environment). Hence, it can be concluded that the environmental concerns of airlines are another indicator which can influence the passenger's image of airlines.

\section{Conclusions}

This study contributed to the body of knowledge by explaining the relationship between corporate image dimensions and passengers airline hospitality expectations using the perceived service quality theory (PSQ). Perceived service quality theory (PSQ) explains the connection between corporate image antecedents and passenger expectations from airline hospitality. Partial Least Squares (PLS) was used as the primary statistical analysis method to test the hypotheses among 546 air travellers. Findings show that managerial corporate image significantly and positively influence passengers' airline hospitality expectations.

\section{References}

Abratt, R., \& Mofokeng, T.N. (2000). Development and management of corporate image in South Africa. European Journal of Marketing, $35(3), 368-386$.

Andreassen, T.W., \& Lindestad, B. (1998). Customer loyalty and complex services: The impact of corporate image on quality, customer satisfaction and loyalty for customers with varying degrees of service expertise. International Journal of Service Industry Management, 9(1),7-23.

Barclay DW, Thompson R, \& Higgins C. (1995). The partial least squares (PLS) approach to causal modelling: personal computer adoption and use an illustration. Technol Stud, 2(2), 285-309.

Bloemer, J., Ruyter, K., \& Pascal, P. (1998). Investigating drivers of bank loyalty: the complex relationship between image, service quality and satisfaction. International Journal of Bank Marketing, 16,276-286.

Bravo, R., Montaner, T. \& Pina, J.M. (2010): Corporate brand image in retail banking: development and validation of a scale. The Service Industries Journal, 30(8), 1199-1218.

Brodie, R. J. Whittome, J. R.M. \& Brush, G.J. (2009). Investigating the service brand: A customer value perspective. Journal of Business Research, 62, 345-355.

Cameran, M., Moizer, P., \& Pettinicchio, A. (2010). Customer satisfaction, corporate image, and service quality in professional services. The Service Industries Journal, 30(3), 421-435.

Chen, C.F., \& Chang, Y.Y. (2008). Airline brand equity, brand preference, and purchase intentions: The moderating effects of switching costs. Journal of Air Transport Management, 14, 40-42.

Cheng, J.H., Chen, F.Y., \& Chang, Y. H. (2008). Airline relationship quality: An examination of Taiwanese passengers. Tourism Management, 29, 487-499. 
Compeau D.R., Higgins CA, Huff S. (1999). Social cognitive theory and individual reactions to computing technology: a longitudinalstudy. MIS Quarterly, 23(2), 145-158.

Cretu, A. E., \& Brodie, R.J. (2007). The influence of brand image and company reputation where manufacturers market to small firms: A customer value perspective. Industrial Marketing Management, 36,230-240.

Gilbert, D., \& Wong, R.K.C. (2003). Passenger expectations and airline services: a Hong Kong based study. Tourism Management, 24, 519-532.

Gotsi, M., \& Wilson A. M. (2001).Corporate reputation: seeking a definition. Corporate Communications: An International Journal, 6 (1),24-30.

Grönroos, C. (1984). A service quality model and its marketing implications. European Journal of Marketing, 18 (4), 36-44.

Hair, J.F., Black, W.C., Babin, B.J., \& Anderson, R.E. (2010). Multivariate Data Analysis. Prentice-Hall, 7th ed Upper Saddle River, NJ.

Hoenen, A., Karunaratna, A.R., \& Quester, P. G.(2005). Influence of country of origin effects on services: A study of airlines, ANZMAC 2005 Conference: Marketing in International and Cross-Cultural Environments.

Hu, H.H. S., Kandampully, J. \& Juwaheer, T. D. (2009). Relationships and impacts of service quality, perceived value, customer satisfaction, and image: an empirical study. The Service Industries Journal, 29(2), 111-125.

Kandampully, J., \& Hu, H. (2007). Do hoteliers need to manage image to retain loyal customer? International Journal of Contemporary Hospitality Management, 19(6), 435-443.

Kijewski, V. Yoon, E. \& Guffey, H. (1993). The effects of information and company reputation on intention to buy a business service. Journal of Business Research, 27,215-228.

Kim, J.H., \& Hyun, Y.J. (2011). A model to investigate the influence of marketing mix efforts and corporate image on brand equity in the IT software sector. Industrial Marketing Management, 40,424-438.

Nunnally, J.C. (1978). Psychometric Theory (2nd Eds.) MC Graw Hill, New York.

O'Leary-Kelly, S.W. \& Vokurka, R.J.(1998). The empirical assessment of construct validity. Journal of Operations Management, 16, $387-$ 405.

Park, J. W., Robertson, R., \& Wu C.L. (2004). The effect of airline service quality on passengers' behavioural intentions: a Korean case study. Journal of Air Transport Management, 10, 435-439.

Pina, J. M., Martinez, E., de Chernatony, L., \& Drury, S. (2006). The effect of service brand extensions on corporate image an empirical model. European Journal of Marketing 40(1/2), 174-197.

Pizam, A., \& Ellis, T. (1999). Customer satisfaction and its measurement in hospitality enterprises. International Journal of Contemporary Hospitality Management, 11(7), 326-339.

Sekaran U, Bougie R (2010) Research methods for business: a skill building approach. Wiley, UK.

Shapiro, C. (1983). Premiums for High Quality Products as Returns to Reputations. The Quarterly Journal of Economics, 98(4), 659-680.

Walsh, G., Beatty, S. E. Edward M.K. Shiu . (2009). The customer-based corporate reputation scale: Replication and short form. Journal of Business Research, 62,924-930.

Worsfold, P. (1999). HRM, performance, commitment and service quality in the hotel industry. International Journal of Contemporary Hospitality Management, 11(7). 340-348.

Yang, Coates. (2010). Internal marketing: service quality in leisure services. Marketing Intelligence \& Planning, 28(6), 754-769.

Yang, J.T. (2010). Antecedents and consequences of job satisfaction in the hotel industry. International Journal of Hospitality Management, 29(4), 609-619.

Zins, A. H. (2001). Relative attitude and commitment in customer loyalty models, some experience in the commercial airline industry. International Journal of Service Industry Management, 12(3), 269-294. 